\title{
A Herbal Formula, Atofreellage, Ameliorates Atopic Dermatitis-Like Skin Lesions in an NC/Nga Mouse Model
}

\author{
Won-Yong Kim ${ }^{1}$, Hyeong-Geug Kim ${ }^{1}$, Hye-Won Lee ${ }^{2}$, Jin-Seok Lee ${ }^{1}$, Hwi-Jin Im ${ }^{1}$, \\ Hyo-Seon Kim ${ }^{1}$, Sung-Bae Lee ${ }^{1}$ and Chang-Gue Son ${ }^{1, *}$ \\ Received: 7 November 2015 ; Accepted: 21 December 2015 ; Published: 25 December 2015 \\ Academic Editor: Derek J. McPhee \\ 1 Liver and Immunology Research-Center, Daejeon Oriental Hospital of Daejeon University, 176-9, \\ Daeheung-ro, Jung-Gu, Daejeon 34929, Korea; godunga3@naver.com (W.-Y.K.); winakim@dju.kr (H.-G.K.); \\ neptune26ljs@naver.com (J.-S.L.); lastdohee@gmail.com (H.-J.I.); khs910707@hanmail.net (H.-S.K.); \\ sky161300@naver.com (S.-B.L.) \\ 2 TKM-Based Herbal Drug Research Group, Korea Institute of Oriental Medicine, Daejeon 34054, Korea; \\ hwlee@kiom.re.kr \\ * Correspondence: ckson@dju.ac.kr; Tel.: +82-42-229-6723; Fax: +82-42-257-6398
}

\begin{abstract}
We evaluated the anti-atopic dermatitis (AD) effect of Atofreellage (AF), a herbal formula composed of 10 medicinal plants. AD was induced on the dorsal skin areas of NC/Nga mice (male, seven weeks old) by daily application of 2,4-dinitrochlorobenzene (DNCB) for five weeks. After three weeks of DNCB application, $200 \mu \mathrm{L}$ of $\mathrm{AF}(0,25,50 \mathrm{or} 100 \mathrm{mg} / \mathrm{mL})$ was applied to the skin lesions. Histological findings, blood cell populations, serum levels of immunoglobulin E (IgE), histamine, pro-inflammatory cytokines, and inflammatory signaling in the skin tissue, and T-helper cell type $2\left(\mathrm{Th}_{2}\right)$-related cytokines in splenocytes were analyzed. Histopathological findings showed AF treatment notably attenuated the thickness of dorsal skin, and eosinophil infiltration. AF treatment (especially $100 \mathrm{mg} / \mathrm{mL}$ ) also demonstrably ameliorated the blood cell population abnormalities, as the notable elevation of serum concentrations of IgE, histamine, TNF- $\alpha$, IL- 6 and IL- $1 \beta$ were remarkably normalized by AF treatment. Western blot analysis evidenced the apparent normalization of inflammatory signals (ERK, p38 MAP kinase, JNK, and NF- $\mathrm{kB}$ ) in the skin tissue. Additionally, AF treatment notably attenuated the activation of $\mathrm{Th}_{2}$-dominant cytokines (IL-13, IL-4, and IL-5) in Con A-treated splenocytes in an $e x$ vivo assay. In conclusion, this study provides experimental evidence for the clinical relevance of Atofreellage.
\end{abstract}

Keywords: atopic dermatitis; herbal medicine; inflammation; NC/Nga murine model

\section{Introduction}

Atopic dermatitis (AD), a critical medical issue, is a chronically relapsing inflammatory skin disease. Currently, the global prevalence of $\mathrm{AD}$ is approximately $1 \%$ to $20 \%$ [1]. The morbidity rate of $\mathrm{AD}$ has continuously increased, possibly due to industrialization and urbanization [2]. Moreover, both infants and children are the main subjects suffering from AD, which occasionally distorts healthy development in both physical and emotional terms [3].

The main symptoms of AD are as follows: dry and eczematous skin, erythematous papules, and severe pruritus [4]. Although the pathology of AD remains unclear, it is thought to involve hypersensitivity type 1 immune reactions [5]. The development of AD is mainly attributed to skin barrier defects and the deregulation of both T-helper cell type $1\left(\mathrm{Th}_{1}\right)$ and T-helper cell type $2\left(\mathrm{Th}_{2}\right)$ from the immune system [6]. Additionally, environmental factors such as allergens and microbes appear to play critical roles in the $\mathrm{AD}[7]$. 
The complex and unexplored etiology of AD has made the development of therapeutics difficult. In general, for the past few decades anti-histamine agents, immunosuppressive agents, moisture care therapy, steroid ointments, or localized immunoregulatory agents have been used for treating AD [8,9]. Whole body steroid treatment is often chosen for severe cases of AD [10]. These therapeutics, however, do not radically treat $\mathrm{AD}$, but rather, reduce $\mathrm{AD}$-related symptoms and are frequently associated with side effects or relapse [11]. Accordingly, the above therapies have limitations regarding their use in treating patients with $\mathrm{AD}$, and development of novel remedies as well as establishment of the disease etiology are required [12].

Various herbal plants have traditionally, been used for patients with skin dermatitis. Some herbal plants such as Illicium verum and Catalpa ovata stem bark have a potent effect on AD in animal models $[13,14]$. To invent an herbal medicine-derived remedy for $\mathrm{AD}$, we surveyed the list of medicinal plants traditionally used in clinical practice and conducted an experimental screening using the rat-derived basophilic leukemia cell line RBL-2H3, focusing on the regulation of AD-related actions. We finally selected different plants and made up a formula, named "Atofreellage", consisting of an equal weight of 10 herbal plants: Rhus javanica Linne, Kochia scoparia Schrader, Cnidium monieri Cuss, Houttuynia cordata Thunberg, Schizonepeta tenuifolia Briquet, Sophora flavescens Aiton, Rheum palmatum Linne, Lithospermum erythrorhizon Siebold et Zuccarini, Terminalia chebula Retzins, and Trichosanthes kirilowii Maximowicz. Atofreellage has been applied to AD skin lesions as a homemade "bath preparation" or "lotion type" treatment at Daejeon Oriental Hospital since 2014.

In the present study, we aimed to identify the anti-AD effects of Atofreellage and investigate its underlying pharmacological mechanisms using a 2,4-dinitrochlorobenzene (DNCB)-induced AD model in NC/Nga mice.

\section{Results}

\subsection{Chemical Constitution Analysis of Atofreellage}

The HPLC-based fingerprint of Atofreellage was conducted under the UV wavelength of $340 \mathrm{~nm}$ (Figure 1A), and quantitative analysis was conducted for three compounds. The retention times of gallic acid, caffeic acid and hyperoside were $8.3 \mathrm{~min}, 16.9 \mathrm{~min}$, and $27.3 \mathrm{~min}$, respectively (Figure 1B,C). Gallic acid at approximately $52.6 \pm 0.4 \mathrm{mg} / \mathrm{g}$ was the most abundant component in Atofreellage, followed by hyperoside (16.7 $\pm 0.5 \mathrm{mg} / \mathrm{g}$ ) and caffeic acid (13.4 $\pm 0.2 \mathrm{mg} / \mathrm{g})$, (Figure 1D).
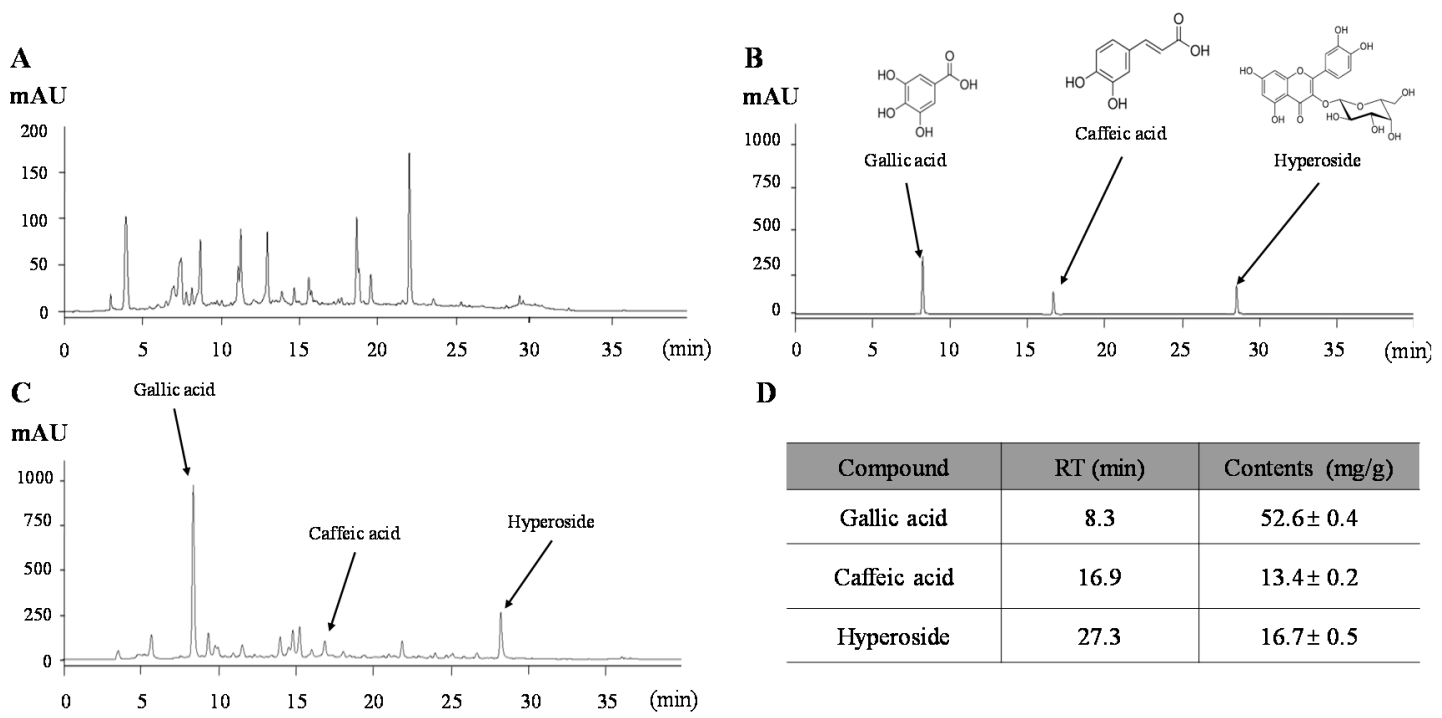

\begin{tabular}{c|c|c}
\hline Compound & RT (min) & Contents (mg/g) \\
\hline Gallic acid & 8.3 & $52.6 \pm 0.4$ \\
\hline Caffeic acid & 16.9 & $13.4 \pm 0.2$ \\
\hline Hyperoside & 27.3 & $16.7 \pm 0.5$ \\
\hline
\end{tabular}

Figure 1. Fingerprint of Atofreellage. Atofreellage and its reference compounds were subjected to HPLC analysis. Histograms of Atofreellage $(\mathbf{A}, \mathbf{C})$ and reference compounds $(\mathbf{B})$ and the quantitative analysis of Atofreellage (D) are presented. 


\subsection{Effects on the Histopathological Analysis}

Notably, H \& E staining revealed the typical features of inflammatory cell infiltration into the skin, which was markedly ameliorated by Atofreellage treatment (Figure 2A). In addition, DNCB treatment drastically increased the thickness of both the epidermal and dermal tissues by approximately 9.3 -fold and 4.8-fold, whereas Atofreellage treatment significantly ameliorated these changes compared with the control group, especially for epidermal tissue ( $p<0.001$ for 50 and $100 \mathrm{mg} / \mathrm{mL}$ Atofreellage, Figure 2A,C). The change in dermal thickness did not reach statistical significance (Figure 2D). Moreover, toluidine blue staining indicated the prominent number of mast cells in the dermal area, whereas Atofreellage treatment considerably decreased the number of mast cells (Figure 2B). The mast cell infiltrations were drastically increased as 21.4-fold in control group as compared with normal group, whereas Atofreellage treatment significantly reduced them as compared with control group (Figure 2E).

Dexamethasone treatment also remarkably ameliorated the above alterations, similar to Atofreellage treatment.

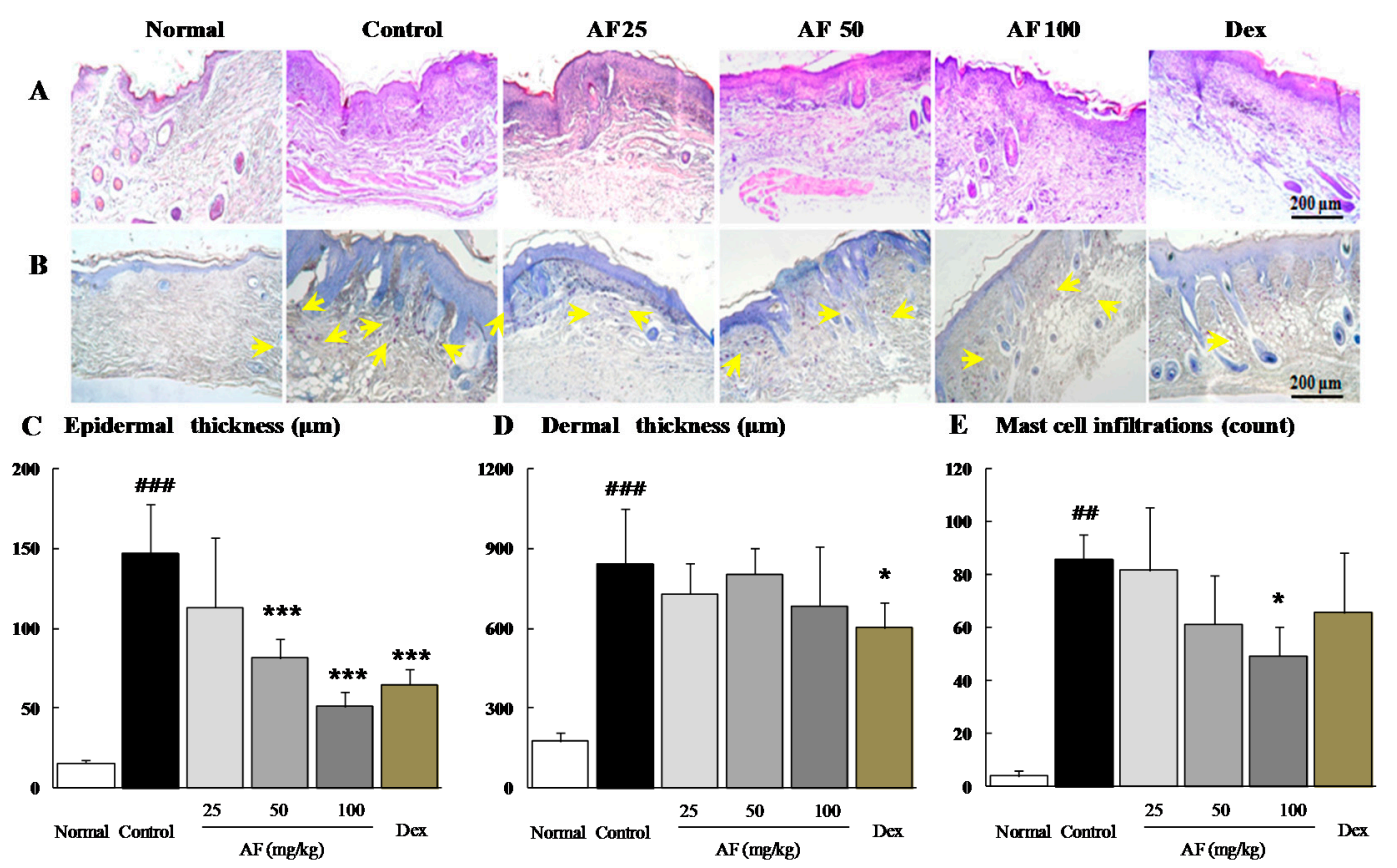

Figure 2. Histopathological findings. Dorsal skin lesions of NC/Nga mice were stained with H \& E (A) and toluidine blue staining (B). All images were analyzed under 100 $\times$ magnification. The skin thicknesses of epidermal (C) and dermal (D) tissues, and infiltration mast cells (E) were analyzed. The data are expressed as the mean \pm SD $(n=8)$. Arrows indicated the infiltration of basophils. \#\# $p<0.01$ and ${ }^{\# \# \#} p<0.001$, compared with the normal group; ${ }^{*} p<0.05$ and ${ }^{* * *} p<0.001$, compared with the control group.

\subsection{Effects on the Peripheral Blood Cell Populations}

DNCB treatment significantly increased total leukocyte counts in the peripheral blood by 1.5 -fold compared with the normal group, and the numbers of subpopulations, especially neutrophils, eosinophils, and basophils were increased by approximately 2.3-, 12.0-, and 5.0-fold compared with the normal group. These alterations were significantly attenuated by Atofreellage treatment compared with the control group $(p<0.05$ for $100 \mathrm{mg} / \mathrm{mL}$ Atofreellage for neutrophils and eosinophils, $p<0.05$ or $<0.01$ for 25 or $100 \mathrm{mg} / \mathrm{mL}$ Atofreellage, respectively, for basophils; Table 1). In the dexamethasone treatment group, the altered numbers of neutrophils, eosinophils, and basophils were significantly normalized. 
Table 1. Effects on the peripheral blood cell population.

\begin{tabular}{|c|c|c|c|c|c|c|}
\hline \multirow[b]{2}{*}{ Categories } & \multirow[b]{2}{*}{ Normal } & \multirow[b]{2}{*}{ Control } & \multicolumn{3}{|c|}{ Atofreellage $(200 \mu \mathrm{L} / \mathrm{Head})$} & \multirow{2}{*}{$\begin{array}{l}\text { Dexamethasone } \\
3 \mathrm{mg} / \mathrm{kg}\end{array}$} \\
\hline & & & $25 \mathrm{mg} / \mathrm{mL}$ & $50 \mathrm{mg} / \mathrm{mL}$ & $100 \mathrm{mg} / \mathrm{mL}$ & \\
\hline $\mathrm{WBC}(\mathrm{k} / \mu \mathrm{L})$ & $2.34 \pm 0.65$ & $3.51 \pm 0.75^{\#}$ & $3.58 \pm 1.04$ & $2.75 \pm 0.62$ & $2.94 \pm 0.61$ & $2.80 \pm 0.16$ \\
\hline Lymphocyte $(\mathrm{k} / \mu \mathrm{L})$ & $1.68 \pm 0.31$ & $1.97 \pm 0.57$ & $2.19 \pm 0.44$ & $1.83 \pm 0.35$ & $2.21 \pm 0.42$ & $2.1 \pm 0.22$ \\
\hline Monocyte $(\mathrm{k} / \mu \mathrm{L})$ & $0.06 \pm 0.01$ & $0.07 \pm 0.02$ & $0.07 \pm 0.02$ & $0.07 \pm 0.01$ & $0.06 \pm 0.02$ & $0.07 \pm 0.01$ \\
\hline Neutrophil $(\mathrm{k} / \mu \mathrm{L})$ & $0.59 \pm 0.11$ & $1.33 \pm 0.20 \#$ & $1.18 \pm 0.15$ & $0.78 \pm 0.24$ & $0.59 \pm 0.16 *$ & $0.56 \pm 0.13 *$ \\
\hline Eosinophil $(\mathrm{k} / \mu \mathrm{L})$ & $0.01 \pm 0.01$ & $0.12 \pm 0.03$ & $0.08 \pm 0.06$ & $0.08 \pm 0.06$ & $0.08 \pm 0.03 *$ & $0.04 \pm 0.04 * *$ \\
\hline Basophil $(\mathrm{k} / \mu \mathrm{L})$ & $0.01 \pm 0.00$ & $0.05 \pm 0.01$ & $0.03 \pm 0.02 *$ & $0.03 \pm 0.02 * *$ & $0.02 \pm 0.02 * *$ & $0.02 \pm 0.02 * *$ \\
\hline
\end{tabular}

The data are expressed as the mean $\pm \mathrm{SD}(n=8) .{ }^{\#} p<0.05,{ }^{\# \#} p<0.01$ and ${ }^{\# \#} p<0.001$ compared with the normal group; ${ }^{*} p<0.05$ and ${ }^{* *} p<0.01$ compared with the control group.

\subsection{Effects on Serum IgE and Histamine}

DNCB treatment drastically elevated serum IgE levels by approximately 17.7-fold compared with the normal group, whereas Atofreellage treatment significantly decreased this abnormal elevation in a dose-dependent manner ( $p<0.001$ for 25 to $100 \mathrm{mg} / \mathrm{mL}$ Atofreellage, Figure 3A). Serum histamine levels were remarkably increased by approximately 4.4 -fold in the DNCB-treated control group compared with the normal group, while Atofreellage treatment significantly attenuated those abnormalities ( $p<0.01$ for 50 and $100 \mathrm{mg} / \mathrm{mL}$ Atofreellage, Figure 3B). Treatment with dexamethasone significantly attenuated the changes in both serum IgE and histamine levels.

A

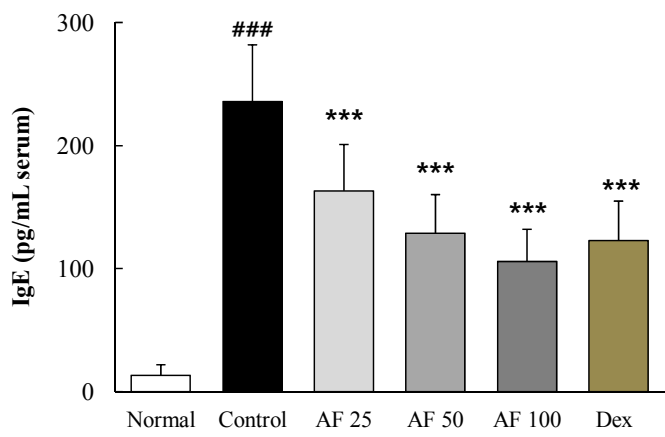

B

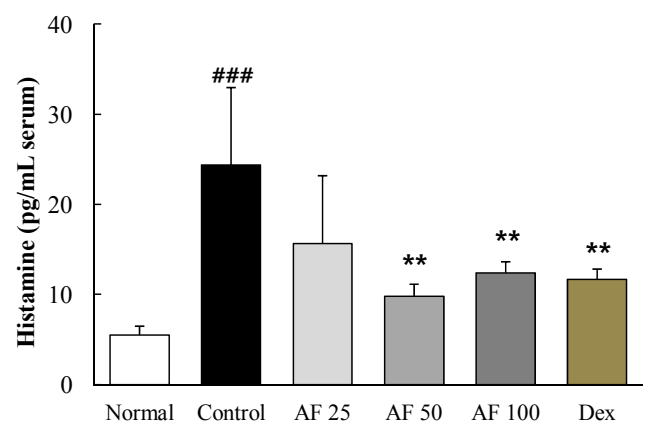

Figure 3. $\operatorname{IgE}$ and histamine in serum. Serum levels of $\operatorname{IgE}(\mathbf{A})$ and histamine $(\mathbf{B})$ were measured using ELISA kit. The data are expressed as the mean $\pm \operatorname{SD}(n=8)$. \#\# $p<0.001$, compared with the normal group; $^{* *} p<0.01$ and ${ }^{* * *} p<0.001$, compared with the control group.

\subsection{Effects on Serum Pro-Inflammatory Cytokines}

DNCB treatment markedly increased serum levels of three pro-inflammatory cytokines, TNF- $\alpha$ by 2.1 -fold, IL- 6 by 2.0 -fold and IL-1 $\beta$ by approximately 2.1 -fold, compared with the normal group. These alterations in serum cytokine levels were significantly attenuated by Atofreellage treatment compared with the control group, including the alterations in TNF- $\alpha(p<0.001$ for $100 \mathrm{mg} / \mathrm{mL}$ Atofreellage) and in both IL-6 and IL-1 $\beta$ ( $p<0.001$ for 25 to $100 \mathrm{mg} / \mathrm{mL}$ Atofreellage) (Figure 4A-C). Dexamethasone showed similar effects on the serum levels of TNF- $\alpha$, IL- 6 and IL- $1 \beta$.

\subsection{Effects on Inflammatory Signaling Pathways}

DNCB treatment remarkably increased the protein levels of nuclear NF- $\mathrm{kB}$ in the skin tissues compared with those in the normal group, whereas Atofreellage treatment significantly reduced NF- $\mathrm{KB}$ activation compared with the control group ( $p<0.01$ for $100 \mathrm{mg} / \mathrm{mL}$ Atofreellage, Figure 5A,B). MAP kinase signaling molecules were considerably activated by DCNB treatment compared with the normal group, whereas Atofreellage treatment significantly attenuated the abnormally increased protein activities for $\mathrm{p}$-JNK ( $p<0.05$ or $<0.01$ for 50 and $100 \mathrm{mg} / \mathrm{mL}$ Atofreellage), p-ERK $(p<0.05$ or $<0.001$ for 25 and $100 \mathrm{mg} / \mathrm{mL}$ Atofreellage), and p38 MAP kinase ( $p<0.01$ or $<0.001$ for 25 to $100 \mathrm{mg} / \mathrm{mL}$ 
Atofreellage) (Figure 5A,B). Treatment with dexamethasone also led to the normalization of both NF- $\mathrm{kB}$ and MAP kinase sub-family activation.
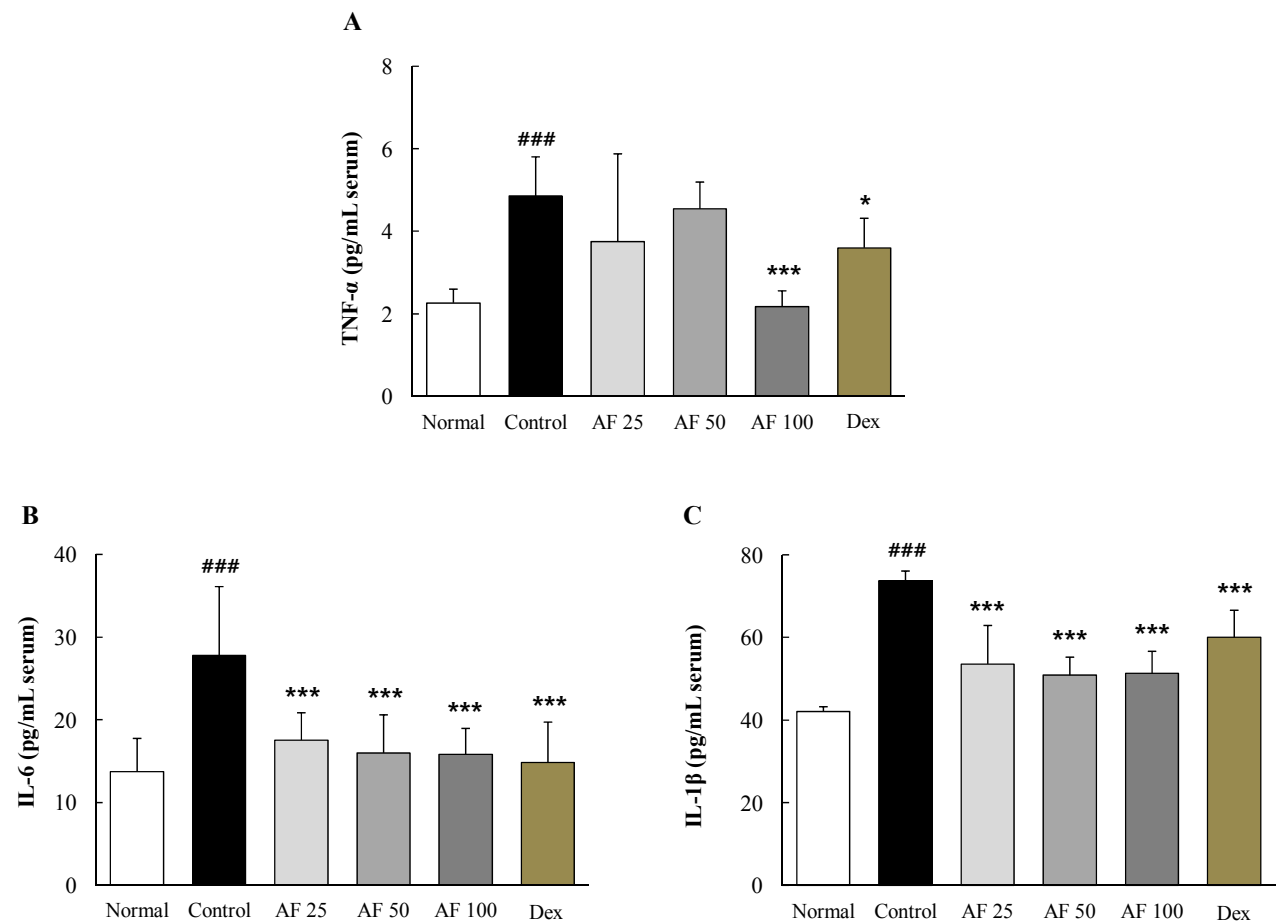

Figure 4. Pro-inflammatory cytokines in the serum. Serum levels of pro-inflammatory cytokines, including TNF- $\alpha$ (A); IL-6 (B); and IL-1 $\beta$ (C), were measured using ELISA kits. The data are expressed as the mean $\pm \mathrm{SD}(n=8) .{ }^{\# \#} p<0.001$, compared with the normal group; ${ }^{*} p<0.05$ and ${ }^{* * *} p<0.001$, compared with the control group.

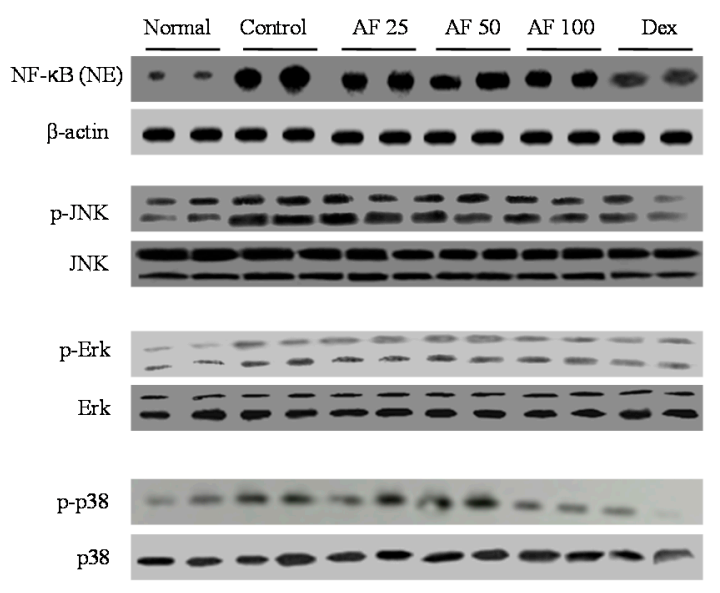

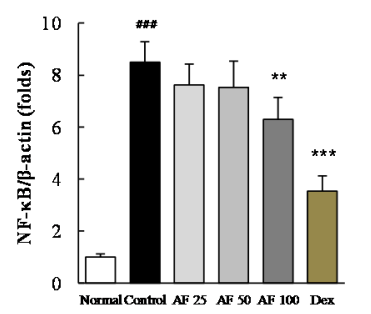
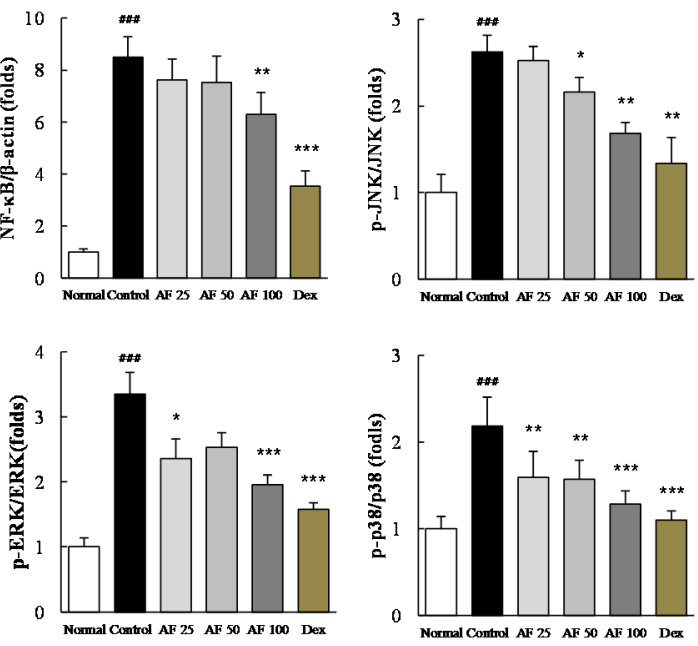

Figure 5. Western blot analysis of inflammatory signaling pathway components. Protein levels of NF- $\mathrm{B}$ and MAP kinase sub-family members were determined by western blotting (A). Protein levels were quantified using ImageJ software (B). The data are expressed as the mean \pm SD $(n=8)$. ${ }^{\# \# \#} p<0.001$ compared with the normal group; ${ }^{*} p<0.05$, ${ }^{* *} p<0.01$, and ${ }^{* * *} p<0.001$, compared with the control group. 


\subsection{Effects on $T h_{2}$ Cell-Related Cytokines in Primary Cultures of Splenocytes}

In ex vivo primary splenocytes stimulated by Con A, the control group showed considerably higher levels of $\mathrm{Th}_{2}$ cell-related cytokines, with increases of approximately 3.8-, 2.4-, and 5.9-fold for IL-13, IL-4, and IL-5, respectively, compared with the normal group. The Atofreellage treatment groups showed significant attenuation of those changes in the levels of IL-13 $(p<0.05$ for $100 \mathrm{mg} / \mathrm{mL}$ Atofreellage, Figure 6A) and both IL-4 and IL-5 ( $p<0.001$ for 25 to $100 \mathrm{mg} / \mathrm{mL}$ Atofreellage, Figure 6B,C). Dexamethasone had positive effects on the levels of these cytokines.
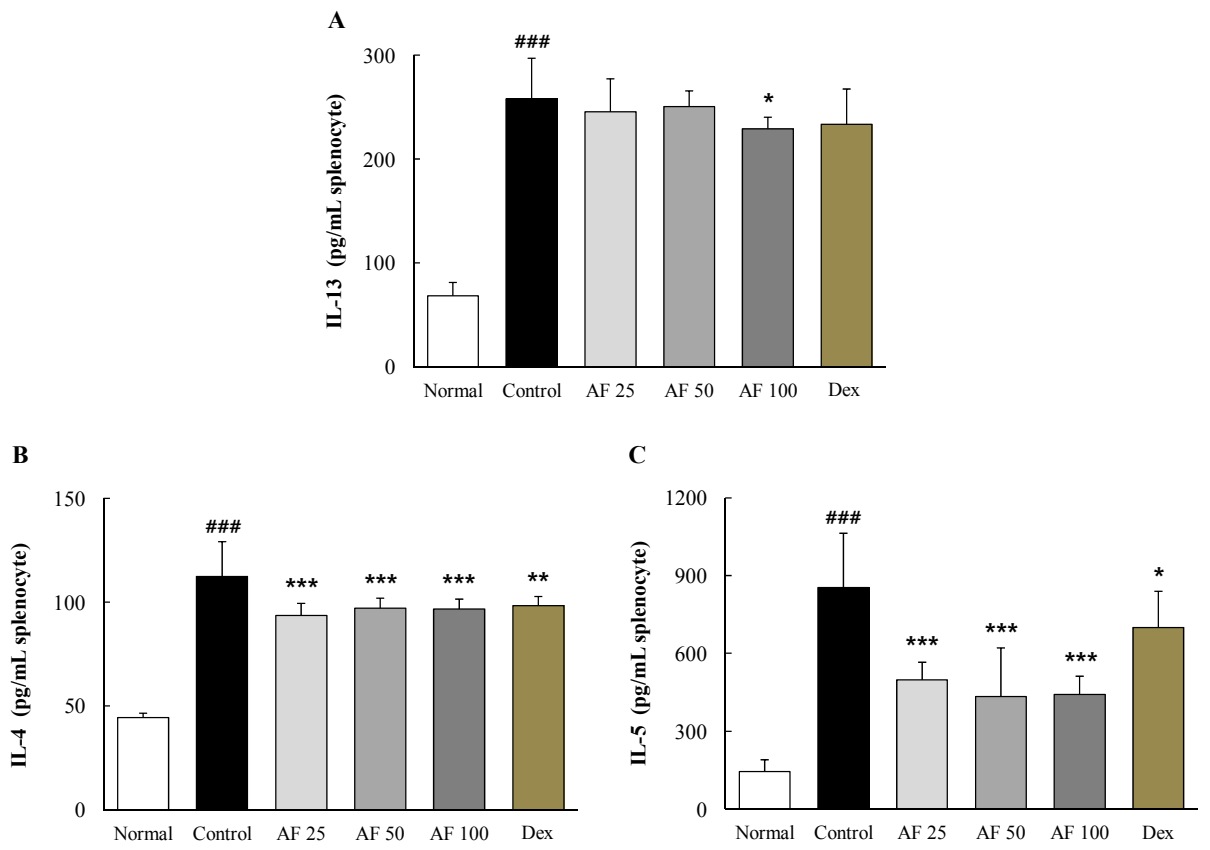

Figure 6. Th 2 -related cytokines in cultured splenocytes. The levels of IL-13 (A); IL-4 (B) and IL-5 (C) in culture media were measured using ELISA kits. The data are expressed the mean \pm SD $(n=8)$. \#\#\# $p<0.001$, compared with the normal group; ${ }^{*} p<0.05$ and ${ }^{* * *} p<0.001$, compared with the control group.

\section{Discussion}

$\mathrm{AD}$ is a chronic inflammatory skin disease that occurs most frequently in both infants and children, and is increasing in prevalence [15]. Many groups have tried to identify therapeutic means to ameliorate $\mathrm{AD}$, but limited success has been achieved to date, and there remains a great demand for novel AD therapeutics. The development of therapeutics has focused on the modulation of pathological mechanism(s) of the $\mathrm{AD}$, likely including the inhibition of $\mathrm{Th}_{2}$ responses, the decrease of IgE production, and the production of anti-histamine effects [16,17]. Recently, medicinal plants have been widely adapted as an important resource in drug development for treating AD based on their long history of traditional clinical uses and relatively safe application [18].

In the present study, we aimed to explore the pharmacological effects of a drug mixture comprising multiple herbs called Atofreellage. We adapted a DNCB-induced AD model in NC/Nga mice; this model has been widely used for experimental studies due to its close resemblance to human AD [19]. Regarding the present $\mathrm{AD}$ remedies, applying drugs to the skin lesion is important to consider because the main complaints of $\mathrm{AD}$ include pruritus, dryness, and psoriasis on skin regions [20]. We therefore applied Atofreellage to the dorsal areas of AD-induced NC/Nga mice. As expected, the DNCB treatment induced thickening of the dermis and epidermis as well as the infiltration of inflamed cells on dermal areas of the skin lesion, which is a general feature of the histopathological characteristics in AD [21]. These histopathological alterations were significantly ameliorated by Atofreellage (Figure 2A-D). 
Although the mechanistic details are not known, the abnormal accelerated production of IgE and antigen cross-linking of IgE on the receptors of mast cells and eosinophils followed by the eruption of histamine have been well known as the sequential events causing the symptoms of AD [5]. Accordingly, the elevated serum levels of IgE and histamine are a classical feature of AD; these are then considered as the main parameters to determine anti-atopic effects in many studies $[22,23]$. Several studies showed high levels of serum IgE and histamine in children with severe AD [24,25]. We observed that the dermal application of Atofreellage (especially 50 or $100 \mathrm{mg} / \mathrm{mL}$ ) showed a similar efficacy as the oral administration of dexamethasone on the both $\operatorname{IgE}$ and histamine in the serum levels (Figure 3A,B). In the current study, we used as a positive drug dexamethasone, which is a strong immunosuppressant that has been used locally or systematically for severe cases of AD [26].

The imbalance between $\mathrm{Th}_{1}$ and $\mathrm{Th}_{2}$ in the development and progression of $\mathrm{AD}$ is well known; a $\mathrm{Th}_{2}$-dominant status stimulates the excessive production of IgE and the activation of mast cells [22]. Therefore, the modulation of $\mathrm{Th}_{2}$ cells has also been mainly targeted for $\mathrm{AD}$ remedies [27]. $\mathrm{Th}_{2}$-related cytokines, including IL-4, IL-5, and IL-13, can also cause excessive accumulation of mast cells, basophils, eosinophils and dendritic cells in skin lesions [5]. In the present study, the production of IL-4, IL-5, and IL-13 by splenocytes in ex vivo assays was notably modulated in Atofreellage-treated groups compared with the control group (Figure 6A-C). The mast cells have the same characteristics as basophils, and their filtration in dermal lesions was notably reduced by Atofreellage treatment, as shown with toluidine blue staining (Figure 2A). Mast cells and basophils release inflammatory chemicals, including histamine, while eosinophils mediate late-phase reactions such as destruction of the surrounding tissue at sites of the $\mathrm{Th}_{2}$-dominated inflammation [28].

The above findings were well supported by the effects of Atofreellage on the leukocyte cell number measurements in the peripheral blood levels. Atofreellage treatment significantly inhibited the increase of basophils and eosinophils in the peripheral blood (Table S1); the numbers of these two cell populations are frequently increased in patients suffering from $\mathrm{AD}$ [29]. AD is also a typical chronic relapsing inflammatory disease, especially in the case of localized skin lesions, and is an obstinate disease. Generally, pro-inflammatory cytokines, including TNF- $\alpha$, IL-6, and IL- $1 \beta$, are dominantly increased during the development or progression of $\mathrm{AD}$ [30]. In the current study, we found that the serum levels of TNF- $\alpha$, IL-6, and IL- $1 \beta$ were markedly increased during DNCB-treated AD mode; however these increases were significantly ameliorated by Atofreellage treatment (Figure 4A-C).

Moreover, NF- $\mathrm{kB}$ and MAP kinase play critical roles in most inflammation by modulating the secretion of pro-inflammatory cytokines [30]. Previous studies documented that the suppression of MAP kinase activation led to reduction the number of mast cells, which are involved in the inflammatory response [26]. Based on the deep linkage between the inflammatory response during AD and MAP kinase signaling cascade molecules [31], thus we further explored the activities of JNK, ERK, and p38 as well as NF- $\kappa B$ in dermal samples. In our study, the excessively over-activated molecules due to DCNB application, but they were remarkably inhibited by Atofreellage treatment (Figure 5A,B). These results support the underlying mechanisms at least partially explaining the anti-atopic effect of Atofreellage.

Atofreellage was formulated based on extensive clinical experience and experimental screening for IL-4 and IL-13 inhibitory activity. We confirmed the reproducibility of Atofreellage using HPLC. The three most representative chemical compounds in Atofreellage are gallic acid, caffeic acid, and hyperoside (Figure 1A-D). In fact, among the herbs comprising Atofreellage, several herbs, including R. javanica Linne, K. scoparia Schrader, C. monieri Cuss, H. cordata Thunberg, S. tenuifolia Briquet, S. flavescens Aiton, R. palmatum Linne, L. erythrorhizon Siebold et Zuccarini, T. chebula Retzins, and T. kirilowii Maximowicz partially showed potent effects on AD [32-37]. Two main compounds, gallic acid and caffeic acid, also showed inhibitory actions on histamine release by mast cells and inflammatory reactions in an AD model $[28,38]$. Especially gallic acid not only substantially suppressed the IL-6, but also ameliorated the activation of MAP kinase signaling pathways, including p38 MAP kinase and JNK in the human basophilic KU812 cells [39]. Meanwhile, caffeic acid showed 
its anti-AD effects via reduction of histamine release in the compound 48/80-induced ICR mouse model [40]. A previous study also reported that the anti-AD effects of Artemisia capillaries, using the Dermatophagoides farinae ointment-induced NC/Nga mice model. Similarly to our study, Artemisia capillaries showed substantially the reduced plasma levels of both histamine and IgE [41], meanwhile this herb contains caffeic acid and hyperoside as main active compounds. Above studies support the pharmacological effects of Atofreellage against AD. The current multiple herb composition of Atofreellage would be disadvantageous in the process of developing an AD remedy due to difficulties in quality control and in the identification of active compounds [42]. The traditional clinical use of herbal medicine, however, generally involves multiple mixtures, which gives the advantage of safety. In addition, multiple herbal formulae exert multiple actions against multiple known or unknown molecular targets to control complex diseases such as AD [43]. Atofreellage has been developed based on the traditional use in clinics and experimental data. We confirmed the absence of cytotoxicity of Atofreellage at $400 \mathrm{mg} / \mathrm{mL}$ in RBL-2H3 cells, a rat-derived mast cell line. We showed herein the clinical relevance of Atofreellage as a skin application remedy and its underlying mechanisms corresponding to the pharmacological effects.

Taken together, our data provide experimental evidence of the pharmaceutical activity of Atofreellage for the treatment of $\mathrm{AD}$. The underlying mechanisms corresponding to the anti-atopic effects of Atofreellage involve the regulation of IgE production, of histamine release via the modulation of $\mathrm{Th}_{2}$-dominant cytokines and anti-inflammatory activities in dermal lesions and whole blood.

\section{Experimental Section}

\subsection{Chemicals}

The following reagents were used: 2,4-dinitrochlorobenzene (DNCB; Sigma-Aldrich, St. Louis, MO, USA), dexamethasone (Sigma-Aldrich), acetone (Daejung, Gyonggi-do, Korea), olive oil (Sigma-Aldrich), toluidine blue (Sigma-Aldrich), hematoxylin (Acros Organics, Morris Plains, NJ, USA), eosin (Sigma-Aldrich), ethanol (Samchun, Gyeonggi-do, Korea), tris-glycine SDS buffer (LPS Solution, Daejeon, Korea), tris-glycine buffer (LPS Solution), polysorbate 20 (Tween 20,Duchefa Biochemie, Haarlem, The Netherlands), RIPA buffer solution (LPS Solution), formaldehyde solution (Samchun), and bovine serum albumin (Sigma-Aldrich).

\subsection{Preparations of Atofreellage and Chemical Component Analysis}

The 10 types of herbal plants composing Atofreellage (R. javanica Linne, K. scoparia Schrader, C. monieri Cuss, $H$. cordata Thunberg, S. tenuifolia Briquet, S. flavescens Aiton, R. palmatum Linne, L. erythrorhizon Siebold et Zuccarini, T. chebula Retzins, and T. kirilowii Maximowicz, Table S1) were purchased from the Jeong-Seong Oriental Pharmacy Store (Daejeon, Korea), and their identification was confirmed by a professional herbal pharmacist. Atofreellage was prepared as follows: briefly, $100 \mathrm{~g}$ each of the 10 fully dried individual herbs were mixed and boiled in $10 \mathrm{~L}$ of distilled water (DW) for $100 \mathrm{~min}$ at $100{ }^{\circ} \mathrm{C}$ using a high-speed automatic non-pressure earthen pot (Dae-Woong, Seoul, Korea), and the extraction procedure was then repeated with $5 \mathrm{~L}$ of water. Atofreellage was then centrifuged for $30 \mathrm{~min}$ at $1500 \times \mathrm{g}$, and the supernatant was lyophilized using a vacuum-freeze-drying system and stored at $-70^{\circ} \mathrm{C}$. The final extraction yield was $6.5 \%$. Atofreellage was dissolved in distilled water before use, and the remainder was stored at $-70{ }^{\circ} \mathrm{C}$ for future use.

\subsection{Obtaining the Fingerprint of Atofreellage}

For reproducibility, Atofreellage was verified by producing its fingerprint using high-performance liquid chromatography (HPLC). Three reference compounds, gallic acid (vs. T. chebula Retzins), caffeic acid (vs. S. flavescens Aiton and L. erythrorhizon Siebold), and hyperoside (vs. H. cordata Thunberg), were used for additional quantitative analysis. The calibration curves of each chemical compound were obtained by assessing the peak areas at six concentrations in the range from $6.25 \mu \mathrm{g} / \mathrm{mL}$ to $200 \mu \mathrm{g} / \mathrm{mL}$ 
(serial dilution) for all reference compounds. The linearity of the peak area $(\mathrm{y})$ vs. concentration $(\mathrm{x}$, $\mu \mathrm{g} / \mathrm{mL}$ ) curve for each compound was used to calculate the content of the Atofreellage components (Figure 1A-D).

Quantitative analysis was performed using an 1100 series HPLC device (Agilent Technologies, Santa Clara, CA, USA) equipped with an autosampler (G11313A), column oven (GA1316A), binary pump (G1312), diode-array detector, and degasser (GA1379A). The analytical column was a Gemini C18 (4.6 mm $\times 250 \mathrm{~mm}$; particle size, $5 \mu \mathrm{m}$; Phenomenex, Torrance, CA, USA) that was kept at $30{ }^{\circ} \mathrm{C}$ during the analysis. The mobile phase conditions contained $10 \%$ acetonitrile in water with $0.05 \%$ formic acid and $90 \%$ acetonitrile in water. The gradient flow was as follows: $0-30 \mathrm{~min}, 5 \%-95 \% \mathrm{~B} ; 30-40 \mathrm{~min}$, $30 \%-70 \% \mathrm{~B}$; and $40-50 \mathrm{~min}, 80 \%-20 \%$. The analysis was operated at a flow rate of $1.0 \mathrm{~mL} / \mathrm{min}$ and detected at 254 and $340 \mathrm{~nm}$. The injection volume was $10 \mu \mathrm{L}$. The data were acquired and processed using ChemStation software (Agilent Technologies).

\subsection{Animal and Experiment Schedule}

The design and performance of the animal experiment were approved by the Institutional Animal Care and Use Committee of Daejeon University (DJUARB2015-006), and conducted in accordance with the Policy on the Care and Use of Laboratory Animals. A total of forty-eight specific pathogen-free seven-week-old male NC/Nga (NC) mice were purchased from Dae-Han Bio Link (Choong-Book, Korea). All of the mice were acclimated for 1 week. After acclimation, all of the mice were randomly divided into the following six groups ( $n=8$ for each group): normal (vehicle without DNCB treatment), control (DNCB treatment without AF or Dex treatment), AF 25 (Atofreellage $25 \mathrm{mg} / \mathrm{mL}$ with DNCB treatment), AF 50 (Atofreellage $50 \mathrm{mg} / \mathrm{mL}$ with DNCB treatment), AF 100 (Atofreellage $100 \mathrm{mg} / \mathrm{mL}$ with DNCB treatment), and Dex (dexamethasone $3 \mathrm{mg} / \mathrm{kg}$ with DNCB treatment). To induce AD-like skin inflammation, DNCB was applied to the dorsal area of each animal, except for those of the normal group, according to a previously described method, with slight modifications [25]. DNCB (0.4\% or $0.2 \%$ ) was dissolved in an acetone and olive oil solution mixture (3:1) and was topically applied to mice daily for five weeks on the shaved dorsal skin $(0.4 \%$ DNCB for three weeks and then $0.2 \%$ DNCB for the following two weeks). Atofreellage (200 $\mu \mathrm{L}$ of $0,25,50$, or $100 \mathrm{mg} / \mathrm{mL}$, topically applied to the dorsal skin) or dexamethasone (Dex; $3 \mathrm{mg} / \mathrm{kg}$, orally) was given to the corresponding groups daily for 2 weeks, at which point the mice were treated with $0.2 \%$ DNCB (Figure S1).

On the final experimental day, all of the mice were euthanized under ether anesthesia after $12 \mathrm{~h}$ of fasting. After the collection of retro-orbital sinus blood for leukocyte profile analysis, whole blood was isolated from the abdominal vein using 1-mL syringes for peripheral blood cell counts and biochemical analyses. The spleens were immediately removed for ex vivo experiments, and the dorsal skin tissues were removed and immediately fixed in $10 \%$ formalin solution for histopathological examination or were stored at $-70{ }^{\circ} \mathrm{C}$ for protein assays.

\subsection{Histopathological Examination of AD-Like Skin Lesions}

For the histopathological evaluation, freshly removed dorsal skin tissues were fixed in $10 \%$ neutral formalin and then subjected to an automatic tissue paraffin procedure using a programmed cascade. The paraffin-embedded samples were sectioned to a thickness of $4 \mu \mathrm{m}$ and stained with hematoxylin and eosin ( $\mathrm{H} \& \mathrm{E})$ or toluidine blue. After H\&E staining of the skin lesions, hyperplasia of the epidermal and dermal tissues was observed under a microscope $(100 \times$, Olympus IX71, Tokyo, Japan). On one photograph per sample, the lengths of epidermal and dermal tissues were measured in five different, randomly selected areas using Focus Pro histological analysis software (Focus, Daejeon, Korea). For the detection of mast cells or eosinophils in the dermal areas, toluidine blue-stained cells were observed under a visible light microscope $(100 \times$, Olympus IX71). 


\subsection{Analysis of Leukocytes in Peripheral Blood}

Before whole blood collection on the final experimental day, approximately $60-80 \mu \mathrm{L}$ of retro-orbital sinus blood was collected using a heparin-coated capillary tube. The numbers of total leukocytes, lymphocytes, monocytes, neutrophils, eosinophils, and basophils were counted using an automatic analyzer, CELL-DYNs 3200 (Abbott Laboratories, Santa Clara, CA, USA).

\subsection{Measurement of total IgE and Histamine Concentrations in Serum}

Under ether anesthesia conditions, whole blood was collected via the abdominal vein, and serum was obtained by centrifugation of the blood $(3000 \times g, 15 \mathrm{~min})$. The serum levels of total IgE and histamine were determined using enzyme-linked immunosorbent assay (ELISA) kits according to the manufacturers' instructions (Cat. No. 555248, BioLegend, San Diego, CA, USA for IgE; KA1888, Abnova, Taipei City, Taiwan, for histamine).

\subsection{Measurement of Pro-Inflammatory Cytokine Concentrations in Serum}

The serum levels of three pro-inflammatory cytokines, tumor necrosis factor alpha (TNF- $\alpha)$, interleukin-1 beta (IL-1 $\beta$ ), and interleukin-6 (IL-6), were measured using commercial ELISA kits (Biosource, Camarillo, CA, USA; R \& D Systems, Minneapolis, MN, USA).

\subsection{Western Blot Analysis}

From the dorsal skin tissues, western blot analyses were performed to detect the expression of nuclear factor kappa B (NF-KB), c-Jun N-terminal kinase (JNK), phospho-JNK (p-JNK), extracellular signal-regulated kinase (ERK; p42/44), phospho-ERK (p-ERK; p-p42/44), p38 mitogen-activated protein (MAP) kinase (p38 MAP kinase), and phospho-p38 MAP kinase (p-p38 MAP kinase). The skin tissue samples were homogenized in radioimmunoprecipitation assay buffer $(50 \mathrm{mM}$ Tris- $\mathrm{HCl}, \mathrm{pH} 7.4$, $1 \%$ Nonidet P-40, $0.5 \%$ sodium deoxycholate, $150 \mathrm{mM} \mathrm{NaCl}$ ) containing protease inhibitor cocktail (Roche, Indianapolis, IN, USA). To analyze NF-кB protein in the nucleus, the nuclear fraction was isolated using hypertonic buffer (100 mM Tris, $\mathrm{pH} 7.4,2 \mathrm{mM} \mathrm{Na}_{3} \mathrm{VO} 4,100 \mathrm{mM} \mathrm{NaCl}, 1 \%$ Triton X-100, $1 \mathrm{mM}$ EDTA, 10\% glycerol, $1 \mathrm{mM}$ EGTA, 0.1\% SDS, $1 \mathrm{mM} \mathrm{NaF}, 0.5 \%$ deoxycholate, $20 \mathrm{mM} \mathrm{Na}_{4} \mathrm{P}_{2} \mathrm{O}_{7}$ ).

Skin protein extracts (30 $\mathrm{\mu g}$ of each sample) were separated by $10 \%$ sodium dodecyl sulfate-polyacrylamide gel electrophoresis (SDS-PAGE). After blocking membranes using 5\% bovine serum albumin (Sigma-Aldrich) in 0.1\% phosphate-buffered saline with Tween? 20 (PBST), western blotting was performed based on the manufacturer's instructions for the primary antibodies against NF-кB, JNK, p-JNK, ERK (p42/44), p-ERK (p-p42/44), p38 MAP kinase, and p-p38 MAP kinase (Thermo Scientific Co., San Jose, CA, USA). After incubation with primary antibodies and washing, the membranes were then incubated with secondary antibodies (rabbit or mouse) conjugated with peroxidase for $1 \mathrm{~h}$, followed by washing with PBST. The signals were developed using a chemiluminescence detection buffer (ECL Femto Supersignal, Thermo Scientific Co.). The band intensity for all proteins was analyzed using ImageJ software (NIH, Rockville, MD, USA). $\beta$-actin was used as a reference protein.

\subsection{Ex Vivo Experiment for the Determination of $\mathrm{Th}_{2}$ Cell-Related Cytokines}

After the spleens were freshly removed from the mice of each experimental group, they were washed in cold PBS (10 mM, pH 7.4) twice. For primary cell culture, the splenocytes were isolated and then seeded into 6-well microplates at a density of $2 \times 106 / \mathrm{mL}$. The primary splenocytes were incubated in DMEM (Dulbecco's modified Eagle's medium, Lonza, Basel, Switzerland) containing $10 \%$ fetal bovine serum (FBS) overnight, and the medium was then changed. The splenocytes were stimulated with concanavalin A (ConA; $5 \mu \mathrm{g} / \mathrm{mL}$, Sigma, San Diego, CA, USA) for 72 h. Protein levels of IL-13, IL-4, and IL-5 in the supernatants were determined using ELISA kits (from R \& D Systems, for IL-13 and IL-4; BioLegend for IL-5). 


\subsection{Statistical Analysis}

All data are expressed as the mean \pm standard deviation (SD). One-way analysis of variance (ANOVA) was performed using SPSS 20.0 software (IBM SPSS Inc., Chicago, IL, USA), followed by Duncan's multiple comparison tests to compare between groups. Differences with $p<0.05$ were considered statistically significant.

Supplementary Materials: Supplementary materials can be accessed at: http://www.mdpi.com/1420-3049/ $21 / 1 / 35 /$ s1

Acknowledgments: This research was supported by the "Leaders Industry-university Cooperation" Project, supported by the Ministry of Education, Science \& Technology (MEST-201502160001), and the grant of the Traditional Korean Medicine R \& D Project, Ministry of Health \& Welfare, Republic of Korea (HI12C-1920-010014).

Author Contributions: Won Yong Kim and Chang Gue Son conceived and designed the study. Won Yong Kim, Hye Won Lee, Hyo Seon Kim, and Sung Bae Lee performed the experiments and the statistical analysis. Won Yong Kim, Hyeong Geug Kim, Jin Seok Lee, and Hwi Jin Im interpreted the results and wrote the paper. Chang Gue Son supervised the research. All authors read, revised, and approved the final manuscript.

Conflicts of Interest: The authors declare no conflict of interest.

\section{References}

1. DaVeiga, S.P. Epidemiology of atopic dermatitis: A review. Allergy Asthma Proc. 2012, 33, 227-234. [CrossRef] [PubMed]

2. Berke, R.; Singh, A.; Guralnick, M. Atopic dermatitis: An overview. Am. Fam. Phys. 2012, 86, 35-42.

3. Levy, R.M.; Gelfand, J.M.; Yan, A.C. The epidemiology of atopic dermatitis. Clin. Dermatol. 2003, 21, $109-115$. [CrossRef]

4. Navi, D.; Saegusa, J.; Liu, F.T. Mast cells and immunological skin diseases. Clin. Rev. Allergy Immunol. 2007, 33, 144-155. [CrossRef] [PubMed]

5. Leung, D.Y.; Bieber, T. Atopic dermatitis. Lancet 2003, 361, 151-160. [CrossRef]

6. Bantz, S.K.; Zhu, Z.; Zheng, T. The atopic March: Progression from atopic dermatitis to allergic rhinitis and asthma. J. Clin. Cell. Immunol. 2014, 5, 202. [PubMed]

7. Braun-Fahrlander, C. Environmental exposure to endotoxin and other microbial products and the decreased risk of childhood atopy: Evaluating developments since April 2002. Curr. Opin. Allergy Clin. Immunol. 2003, 3, 325-329. [CrossRef] [PubMed]

8. Simpson, E.L. Atopic dermatitis: A review of topical treatment options. Curr. Med. Res. Opin. 2010, 26, 633-640. [CrossRef] [PubMed]

9. Kim, J.E.; Lee, Y.B.; Lee, J.H.; Kim, H.S.; Lee, K.H.; Park, Y.M.; Cho, S.H.; Lee, J.Y. Disease awareness and management behavior of patients with atopic dermatitis: A questionnaire survey of 313 patients. Ann. Dermatol. 2015, 27, 40-47. [CrossRef] [PubMed]

10. Madan, V.; Griffiths, C.E. Systemic ciclosporin and tacrolimus in dermatology. Dermatol. Ther. 2007, 20, 239-250. [CrossRef] [PubMed]

11. Slater, N.A.; Morrell, D.S. Systemic therapy of childhood atopic dermatitis. Clin. Dermatol. 2015, 33, $289-299$. [CrossRef] [PubMed]

12. Williams, H. New treatments for atopic dermatitis. BMJ 2002, 324, 1533-1534. [CrossRef] [PubMed]

13. Sung, Y.Y.; Yang, W.K.; Lee, A.Y.; Kim, D.S.; Nho, K.J.; Kim, Y.S.; Kim, H.K. Topical application of an ethanol extract prepared from Illicium verum suppresses atopic dermatitis in NC/Nga mice. J. Ethnopharmacol. 2012, 144, 151-159. [CrossRef] [PubMed]

14. Yang, G.; Choi, C.H.; Lee, K.; Lee, M.; Ham, I.; Choi, H.Y. Effects of Catalpa ovata stem bark on atopic dermatitis-like skin lesions in NC/Nga mice. J. Ethnopharmacol. 2013, 145, 416-423. [CrossRef] [PubMed]

15. Spergel, J.M.; Paller, A.S. Atopic dermatitis and the atopic march. J. Allergy Clin. Immunol. 2003, 112, S118-S127. [CrossRef] [PubMed]

16. Leung, D.Y. Atopic dermatitis: New insights and opportunities for therapeutic intervention. J. Allergy Clin. Immunol. 2000, 105, 860-876. [CrossRef] [PubMed] 
17. Akdis, C.A.; Akdis, M.; Bieber, T.; Bindslev-Jensen, C.; Boguniewicz, M.; Eigenmann, P.; Hamid, Q.; Kapp, A.; Leung, D.Y.; Lipozencic, J.; et al. Diagnosis and treatment of atopic dermatitis in children and adults: European Academy of Allergology and Clinical Immunology/American Academy of Allergy, Asthma and Immunology/PRACTALL Consensus Report. Allergy 2006, 61, 969-987. [CrossRef] [PubMed]

18. Chen, H.Y.; Lin, Y.H.; Wu, J.C.; Hu, S.; Yang, S.H.; Chen, J.L.; Chen, Y.C.; Lo, S.S. Use of traditional Chinese medicine reduces exposure to corticosteroid among atopic dermatitis children: A 1-year follow-up cohort study. J. Ethnopharmacol. 2015, 159, 189-196. [CrossRef] [PubMed]

19. Shiohara, T.; Hayakawa, J.; Mizukawa, Y. Animal models for atopic dermatitis: Are they relevant to human disease? J. Dermatol. Sci. 2004, 36, 1-9. [CrossRef] [PubMed]

20. Fernandez-Anton Martinez, M.C.; Leis-Dosil, V.; Alfageme-Roldan, F.; Paravisini, A.; Sanchez-Ramon, S.; Suarez Fernandez, R. Omalizumab for the treatment of atopic dermatitis. Actas DermoSifiliogr. 2012, 103, 624-628. [CrossRef] [PubMed]

21. Zhang, E.Y.; Chen, A.Y.; Zhu, B.T. Mechanism of dinitrochlorobenzene-induced dermatitis in mice: Role of specific antibodies in pathogenesis. PLoS ONE 2009, 4, e7703. [CrossRef] [PubMed]

22. Sicherer, S.H.; Wood, R.A.; American Academy of Pediatrics Section on Allergy and Immunology. Allergy testing in childhood: Using allergen-specific IgE tests. Pediatrics 2012, 129, 193-197. [CrossRef] [PubMed]

23. Theoharides, T.C.; Alysandratos, K.D.; Angelidou, A.; Delivanis, D.A.; Sismanopoulos, N.; Zhang, B.; Asadi, S.; Vasiadi, M.; Weng, Z.; Miniati, A.; et al. Mast cells and inflammation. Biochim. Biophys. Acta 2012, 1822, 21-33. [CrossRef] [PubMed]

24. Kennedy, M.J.; Loehle, J.A.; Griffin, A.R.; Doll, M.A.; Kearns, G.L.; Sullivan, J.E.; Hein, D.W. Association of the histamine $N$-methyltransferase C314T (Thr105Ile) polymorphism with atopic dermatitis in Caucasian children. Pharmacotherapy 2008, 28, 1495-1501. [CrossRef] [PubMed]

25. Stone, K.D.; Prussin, C.; Metcalfe, D.D. IgE, mast cells, basophils, and eosinophils. J. Allergy Clin. Immunol. 2010, 125 (Suppl. S2), S73-S80. [CrossRef] [PubMed]

26. Hebert, A.A.; Koo, J.; Fowler, J.; Berman, B.; Rosenberg, C.; Levitt, J. Desoximetasone 0.25\% and tacrolimus $0.1 \%$ ointments versus tacrolimus alone in the treatment of atopic dermatitis. Cutis 2006, 78, 357-363. [PubMed]

27. Lewis, D.B. Allergy immunotherapy and inhibition of $\mathrm{Th}_{2}$ immune responses: A sufficient strategy? Curr. Opin. Immunol. 2002, 14, 644-651. [CrossRef]

28. Nakamura, A.; Osonoi, T.; Terauchi, Y. Relationship between urinary sodium excretion and pioglitazone-induced edema. J. Diabetes Investig. 2010, 1, 208-211. [CrossRef] [PubMed]

29. Foroughi, S.; Foster, B.; Kim, N.; Bernardino, L.B.; Scott, L.M.; Hamilton, R.G.; Metcalfe, D.D.; Mannon, P.J.; Prussin, C. Anti-IgE treatment of eosinophil-associated gastrointestinal disorders. J. Allergy Clin. Immunol. 2007, 120, 594-601. [CrossRef] [PubMed]

30. Shirakawa, I.; Deichmann, K.A.; Izuhara, I.; Mao, I.; Adra, C.N.; Hopkin, J.M. Atopy and asthma: Genetic variants of IL-4 and IL-13 signalling. Immunol. Today 2000, 21, 60-64. [CrossRef]

31. Wong, C.K.; Ho, C.Y.; Ko, F.W.; Chan, C.H.; Ho, A.S.; Hui, D.S.; Lam, C.W. Proinflammatory cytokines (IL-17, IL-6, IL-18 and IL-12) and Th cytokines (IFN-gamma, IL-4, IL-10 and IL-13) in patients with allergic asthma. Clin. Exp. Immunol. 2001, 125, 177-183. [CrossRef] [PubMed]

32. Matsuda, H.; Tomohiro, N.; Ido, Y.; Kubo, M. Anti-allergic effects of cnidii monnieri fructus (dried fruits of Cnidium monnieri) and its major component, osthol. Biol. Pharm. Bull. 2002, 25, 809-812. [CrossRef] [PubMed]

33. Lee, J.S.; Kim, I.S.; Kim, J.H.; Kim, J.S.; Kim, D.H.; Yun, C.Y. Suppressive effects of Houttuynia cordata Thunb (Saururaceae) extract on $\mathrm{Th}_{2}$ immune response. J. Ethnopharmacol. 2008, 117, 34-40. [CrossRef] [PubMed]

34. Gao, X.K.; Fuseda, K.; Shibata, T.; Tanaka, H.; Inagaki, N.; Nagai, H. Kampo medicines for mite antigen-induced allergic dermatitis in NC/Nga mice. Evid. Based Complement. Altern. Med. 2005, 2, 191-199. [CrossRef] [PubMed]

35. Kim, H.N.; Kim, M.Y.; Choi, C.H.; Kim, B.J.; Kim, K.Y.; Kim, G.Y.; Jeong, H.W.; Kim, H.W. Effect of lithospermi radix on contact dermatitis induced by dinitrofluorobenzene in mice. J. Pharmacopunct. 2012, 15, 7-10. [CrossRef] [PubMed]

36. Shin, Y.K.; Son, H.U.; Kim, J.M.; Heo, J.C.; Lee, S.H.; Kim, J.G. Cinnamomum cassia bark produced by solid-state fermentation with Phellinus baumii has the potential to alleviate atopic dermatitis-related symptoms. Int. J. Mol. Med. 2015, 35, 187-194. [CrossRef] [PubMed] 
37. Zuckerman, G.B.; Bielory, L. Complementary and alternative medicine herbal therapies for atopic disorders. Am. J. Med. 2002, 113 (Suppl. S9A), S47-S51. [CrossRef]

38. Kim, S.H.; Jun, C.D.; Suk, K.; Choi, B.J.; Lim, H.; Park, S.; Lee, S.H.; Shin, H.Y.; Kim, D.K.; Shin, T.Y. Gallic acid inhibits histamine release and pro-inflammatory cytokine production in mast cells. Toxicol. Sci. 2006, 91, 123-131. [CrossRef] [PubMed]

39. Liu, K.Y.; Hu, S.; Chan, B.C.; Wat, E.C.; Lau, C.B.; Hon, K.L.; Fung, K.P.; Leung, P.C.; Hui, P.C.; Lam, C.W.; et al. Anti-inflammatory and anti-allergic activities of Pentaherb formula, Moutan Cortex (Danpi) and gallic acid. Molecules 2013, 18, 2483-2500. [CrossRef] [PubMed]

40. Hossen, M.A.; Inoue, T.; Shinmei, Y.; Minami, K.; Fujii, Y.; Kamei, C. Caffeic acid inhibits compound 48/80-induced allergic symptoms in mice. Biol. Pharm. Bull. 2006, 29, 64-66. [CrossRef] [PubMed]

41. Ha, H.; Lee, H.; Seo, C.S.; Lim, H.S.; Lee, J.K.; Lee, M.Y.; Shin, H. Artemisia capillaris inhibits atopic dermatitis-like skin lesions in Dermatophagoides farinae-sensitized Nc/Nga mice. BMC Complement. Altern. Med. 2014, 14, 100. [CrossRef] [PubMed]

42. World Health Organization. Programme on Traditional Medicine. In General Guidelines for Methodologies on Research and Evaluation of Traditional Medicine; World Health Organization: Geneva, Switzerland, 2000; p. 71.

43. Kim, H.U.; Ryu, J.Y.; Lee, J.O.; Lee, S.Y. A systems approach to traditional oriental medicine. Nat. Biotechnol. 2015, 33, 264-268. [CrossRef] [PubMed]

Sample Availability: Samples of the compounds (gallic acid, caffeic acid, and hyperoside) are available from the authors.

(C) 2015 by the authors; licensee MDPI, Basel, Switzerland. This article is an open access article distributed under the terms and conditions of the Creative Commons by Attribution (CC-BY) license (http://creativecommons.org/licenses/by/4.0/). 